\title{
KORMÁNYZÁST TÁMOGATÓ TUDÁS
}

A Klaus Tschira Alapítvány nemrég egy ritkán tárgyalt témakört vizsgáló tanulmánykötetet tett nyílt hozzáféréssel elérhetővé. A szerkesztőket és a szerzőket az foglalkoztatta elsősorban, mi mondható el napjaink különböző színtereken megnyilvánuló kormányzási tevékenységeinek tudástámogatásáról.

Nézetük szerint a kormányzás (governance) kiterjesztett fogalmát „,a kollektív cselekvések koordinációja" fedi le, messze túllépve a politikai-közigazgatási értelmezési tartományon. Ebből a kiindulópontból pedig olyan sajátosságok és jellegzetességek fakadnak, mint az érintett cselekvők lehetősége és képessége, hogy egymás viselkedésére a kölcsönös függés és összekapcsoltság tudatában gyakorolhassanak hatást (ezt fejezi ki az irányítás hierarchikus modelljével szemben megformált heterarchia fogalma), az egyeztetés (az álláspontok közelítése), a közösen végzett tevékenység szervezésének vagy a legitimációképzésnek újgenerációs technikái és gyakorlatai.

Ahhoz, hogy ez a koordináció bármilyen szervezetben és ,fizikailag szervezett terekben" egyaránt megfelelö módon müködhessen, tudásfolyamatokra és tudástartalmakra van szükség, amelyeknek megújulása igazodik a környezet változásaihoz. A tudás mobilizálható és rekombinálható a kormányzásban részt vevők tapasztalatai vagy bizonyos kérdéskörök külső szakértői révén. S természetesen a megfelelő tudás birtokában megvalósuló kormányzási gyakorlat részben magára a tudásteremtésre és tudáshasználatra is irányulhat: ezt hívjuk tudáskormányzásnak (knowledge governance).

Abból, hogy minden érintett elismeri, a tudás a kormányzás nélkülözhetetlen erőforrása és előfeltétele, korántsem következik, hogy erre aranyszabályként tekintene maga a kormányzási gyakorlat (elég, ha csak a közszférára vagy a közigazgatásra gondolunk). S bár a tudásnak nagy hangsúlyt adni jellegzetes elemzői pozíció, még ez sem elég ahhoz, hogy önálló kutatás és vizsgálódás tárgyává válnának a kormányzást támogató tudás lényegi aspektusai. Nagyon nehezen születik a tudásra vonatkozó tudás.

Ezt a hiányt hivatott részben pótolni e tanulmánykötet, amely több témakör köré rendezi a tárgyát. Számos szerző foglalkozik a kormányzást támogató tudás elérhetőségével, irányításával (control), torzulásával és torzításával (a tartalom manipulálása és a tudás interpretációja). Áttekintik a kormányzást támogató tudások különböző típusait, és nagy hangsúlyt szentelnek a tudásgazdák, a tudások sokféle hordozói legitimációi közti különbségeknek.

A kulcshelyzetbe kerülő tudásoknak a személyes tapasztalat és a szakértői kompetenciák mellett a tudományos üzemek az alapvető forrásai. A kormány- 
zással (vezetéssel, szervezéssel, irányítással, döntéssel) általában foglalkozó, jellemzően gazdaság- és társadalomtudományi beágyazású tudástermelés mellett a közszférában az ágazati és szakpolitikák nyersanyagát jelentő tudományos tudásnak van nagy jelentősége. Nico Stehr a klímapolitika példáján mutatja be, mennyire nélkülözhetetlen a hatékonyságához a tudományos input. Ortwin Renn eközben épp arra hívja fel a figyelmet, hogy a tudományos tudás sem tud válaszolni minden kérdésre. Hiszen a tudomány is termelhet ambivalens, bizonytalan ismereteket, $\mathrm{s}$ a kollektív cselekvés problémáinak csak némely vonatkozásaira érzékeny. A kiinduló pozíció tehát csakis a kockázatok megfelelő kezelése lehet. A kockázatok kormányzása (risk governance) egy olyan szakadatlan tanulási folyamat, amelyet a feldolgozó rendszerekbe újonnan belépö tudások és az azokból fakadó újraértékelési szükségletek táplálnak. Renn röviden ismerteti, hogyan tett ebbe az irányba nagy lépést a részletes ajánlásokat kidolgozó, genfi székhelyü Nemzetközi Kockázatkormányzási Tanács (International Risk Governance Council).*

Számos további tanulmányt hivatkozhatnánk még a kötetböl, amelyek közös jellemzője, hogy nem a tudás központi, megkülönböztetett szerepéről prédikálnak napjaink politikai, gazdasági és társadalmi életének különböző szervezeti színterein. Ehelyett olyan, tipikus problémákra mutatnak rá, amelyek okát a nem megfelelö tudástartalmakban és tudásfolyamatokban kell keresni.

Ilyen tipikus feszültségforrás, amelyet két fejezet (8-9.) is tárgyal, a „központiságot” és a „lokalitást” elválasztó fal, melyet a tudástípusok szükségszerü különbözősége és eltérései húznak fel. Nemcsak a látószögek, hanem a felhasznált ismeretek és azok forrásai is szükségszerủen eltérnek, így a konfliktus szinte bele van kódolva a hierarchiába. Egy tudáskormányzási szemlélet azonban pontosan tudja, hogy megfelelő tudáscserével és tudásmegosztási gyakorlattal ezt a szakadékot át lehet hidalni. Központi szinten is hatóerővé tehető a sokak megélt tapasztalataiból táplálkozó lokális tudástöbblet, a tudományos és szakértői tudás becsatornázásával pedig tovább „dúsítható” a rendelkezésre álló ismerettömeg, amelyből aztán majd helyzetértékelés és cselekvésválasztás fakad - mindkét oldalon.

Hasonló szerkezetben jelentkezik a kormányzat, a települések, a nagyvállalatok, de még a társadalmi szervezetek világában is a „belsősök versus külsősök” dilemma. Ha szükség van a tudáshiány megszüntetésére vagy tudások bevonására az alkalmazkodóképesség fenntartásához, és erre a szervezeten belül nincs elég erőforrás, kézenfekvő kívülről megszerezni azt. Másutt meglévő tudásokhoz vagy tudásszolgáltatásokhoz fordulni - még akkor is, ha ez zavart okoz a legitimációban. De van-e legitimebb dolog a megfelelő tudás birtokában meghozott jó döntésnél?

\footnotetext{
*International Risk Governance Council: http://www.irgc.org. Nem összetévesztendő a lausanne-i székhelyü International Risk Governance Centerrel: https://www.epfl.ch/research/domains/irgc/.
} 
Mindez nemcsak a tudásgazdálkodással, hanem a hatalom megváltozó természetével kapcsolatban is sok tanulsághoz vezet. Számtalan módon nyilvánul meg, pusztán a tudásszerzéshez és felhasználáshoz való szervezeti-közösségi viszony elemzése kapcsán is, mennyire elavulttá lettek a hagyományos, felülről utasító-irányító bürokráciák, miként vált alkalmatlanná a koordinációra sok helyen a piac - és milyen hatékony lehet a közösségi tudástermelés, amely egyúttal tudásfogyasztás is.

A pandémia bebizonyította, hogy a kormányzás tudástámogatásának 19. század végétől formálódó alapmegoldásai már nemzeti szinten is jócskán vesztettek hatékonyságukból, de a nemzetközi közösség szintjén már végképp alkalmatlannak látszanak. A járványvédekezés érzékeny és tudásigényes terület. Nemcsak az azonnal mozgósítható orvosi-közegészségügyi-virológiai ismeretek rendelkezésre állása a fontos, hanem a gyors tudásintegráció, a megfelelő döntések, az azonnali adatcsere, a kölcsönös tájékoztatás, az előrejelző képesség erősítése, a menet közbeni alkalmazkodás is. Aki ezekben a szempontokban alulteljesített, a védekezésben sem tudott megfelelőt nyújtani.

Többek között ez a tanulsága David Osimo friss elemzésének is, amely azt vizsgálta, miként állt helyt, hogyan vált be, milyen mértékben volt használható a járvány elleni védekezésben a szakpolitikai tudást bővítő eszközrendszer, amelyet az Európai Bizottság kutatási és technológiafejlesztési keretprogramja (FP7) segítségével fejlesztettek ki a korábbi években.

A Policy 2.0.-ra elkeresztelt módszertan azokra a rendszerszintủ és összetett, nem lineáris és kevésbé előrejelezhető radikális kihívásokra keresett választ, amellyel a szakpolitikák alakítói az utóbbi időkben szembesültek. A tudásfolyamatok négy szakaszból álló értékláncán (problémaelemzés, szakpolitikai tervezés, megvalósítás irányítása, értékelés) azonosítottak fél tucat tudáskomponenst.

A szakpolitikai modellezést (a döntések várható hatásának előrejelzését és a tényezők egymás közötti kölcsönhatását szimuláló elemzési keretrendszert), a nyilt közadatokat (amelyek egyrészt magas színvonalú adatmegosztással segítik a tudományos kutatásokat, másrészt a tudományos és szakértői elemzéseket teszik azonnal hozzáférhetővé minden potenciális felhasználó számára), az adatvizualizálás új technikáit, amelyek gyorsan és hatékonyan vezetnek átlátáshoz és megértéshez, a kollaboratív döntéshozatalt (az érintett közösségek tagjainak bevonását, amelynek révén a tapasztalatok és a mérlegelés tere többdimenzióssá válik), az állampolgári tudományt (citizen science), amely részt vevő adatszolgáltatóvá téve vonja be az érintetteket az új tudások termelésébe, valamint a viselkedés befolyásolásának, a puha ösztönzőknek a csatasorba állítását.

A járványvédekezés kapcsán a Policy 2.0. eszközvilága felemás eredményeket produkált. Számos, kísérleti szakaszban lévő módszer még nem volt elég érett ahhoz, hogy sikeresen használhassák is azokat. A nagyobb hatékonyságot ígérö tudástechnológiai megoldásokat nehezen tudták összeilleszteni a stabilitást biz- 
tosító intézményi mechanizmusokkal. Zavart okoztak (volna) jól bejáratott folyamatok áttervezésével, így inkább nem nyúltak hozzájuk, a nagy tét miatt nem látszott érdemesnek alternatív megoldásokkal kockáztatni. Így viszont sokkal tisztábban nyilvánult meg a régi, elavult rendszerek minden jól ismert gyermekbetegsége. Ám a folytatólagos fenyegetettség és a növekvő kockázatok árnyékában megkerülhetetlen, hogy szórványmegoldásokkal való kísérletezgetés helyett fokozatosan megkezdődjék a tudásfelhasználás szakpolitikai gyakorlatának teljes átalakítása, izgalmas tudáskormányzási feladatot kínálva a szakértőknek. Hogyan lehet a mindenkori müködőképesség megőrzése mellett, 21. századi eszközökre támaszkodva „átállítani” az előrejelzés, a felkészülés, a döntéshozatal és a tájékoztatás részfeladatainak rendszerét, hogy bármilyen rendkívüli helyzetben jobban teljesíthessenek?

(Johannes Glückler - Gary Herrigel - Michael Handke editors: Knowledge for Governance. Springer, 2020. DOI: 10.1007/978-3-030-47150-7, https://www.researchgate.net/publication/348493742_Knowledge_for_Governance;

David Osimo: Policy 2.0 in the Pandemic World: What Worked, What Didn't and Why; The Lisbon Council, 08 March 2021. https://lisboncouncil.net/policy-2-0in-the-pandemic-world-what-worked-what-didnt-and-why/)

Z. Karvalics László

történész, információs társadalom kutató Szegedi Tudományegyetem Könyvtár- és Humán Információtudományi Tanszék 